\title{
Infusion of Hematopoietic Stem Cells: Types, Characteristics, Adverse and Transfusion Reactions and the Implications for Nursing ${ }^{1}$
}

Ana Carolina de Jesus Vieira Curcioli²

Emilia Campos de Carvalho ${ }^{3}$

Hematopoietic stem cell infusion is an important procedure in Hematopoietic Stem Cell Transplantation (HSCT). This study identifies transfusion and other adverse reactions that can occur during infusion and the nursing care related to the procedure. This epidemiologic study used transplantations performed between 2006 and 2008. A total of 166 transplantations were performed: 114 were autologous, 47 allogeneic and five haploidentical. Three transfusion reactions and 96 adverse reactions were observed. Adverse reactions were related to the presence of cryoprotectant, though the infusion rate and quantity of infused cryoprotectant were not related to the occurrence of reactions. The products were fresh and infused within the recommended time when transfusion reactions occurred. In regard to cell source, lower engraftment time was found in peripheral blood. Nursing documentation is relevant for patients' safety as well to planning an infusion in order to minimize the occurrence of reactions.

Descriptors: Hematopoietic Stem Cell Transplantation / Adverse Effects; Blood Component Transfusion; Nursing.

\footnotetext{
${ }^{1}$ Paper extracted from Master's Thesis "Reações adversas e transfusionais na infusão de células-tronco hematopoéticas: implicações para a enfermagem" presented to Escola de Enfermagem de Ribeirão Preto, Universidade de São Paulo, WHO Collaborating Centre for Nursing Research Development, SP, Brazil.

2 RN, M.Sc. in Nursing. E-mail: carol_curcioli1@hotmail.com.

${ }^{3}$ RN, Ph.D. in Nursing, Full Professor, Escola de Enfermagem de Ribeirão Preto, Universidade de São Paulo, SP, Brazil. E-mail: ecdcava@usp.br.
}

Corresponding Author:

Emilia Campos de Carvalho

Universidade de São Paulo. Escola de Enfermagem de Ribeirão Preto

Av. Bandeirantes, 3900

Bairro Monte Alegre

CEP: 14040-902 Ribeirão Preto, SP, Brasil

E-mail: ecdcava@usp.br 


\title{
Infusão de células-tronco hematopoéticas: tipos, características, reações adversas e transfusionais e implicações para a enfermagem
}

\begin{abstract}
A infusão de células-tronco hematopoéticas é importante procedimento no transplante de células-tronco hematopoéticas. Este estudo se propôs a identificar as reações adversas e transfusionais que podem ocorrer durante a infusão e os cuidados de enfermagem inerentes ao procedimento. Trata-se de estudo epidemiológico em transplantes, ocorridos entre os anos 2006 e 2008. Ocorreram 166 transplantes, sendo 114 autólogos, 47 alogênicos e 5 haploidênticos. Observaram-se três reações transfusionais e 96 reações adversas. As reações adversas estão ligadas à presença do crioprotetor. No entanto, velocidade de infusão e quantidade do crioprotetor infundido não tiveram relação com a ocorrência das reações. Nas reações transfusionais, os produtos eram frescos e infundidos na velocidade preconizada. Quanto às fontes de células, houve menor tempo de enxertia no sangue periférico. A documentação de enfermagem é relevante tanto para a segurança do paciente como para o planejamento da infusão, a fim de minimizar a ocorrência das reações.
\end{abstract}

Descritores: Transplante de Células-Tronco Hematopoéticas / Efeitos Adversos; Transfusão de Componentes Sanguíneos; Enfermagem.

\section{Infusión de células madre hematopoyéticas: tipos, características, reacciones adversas y de transfusión y sus implicaciones para la enfermería}

La infusión de las células madre hematopoyéticas es un importante procedimiento en el trasplante de células madre hematopoyéticas. Este estudio se propuso identificar las reacciones adversas y de transfusión que pueden ocurrir durante la infusión y los cuidados de enfermería inherentes al procedimiento. Se trata de un estudio epidemiológico en trasplantes ocurridos en los años de 2006 a 2008. En ese período ocurrieron 166 trasplantes, siendo 114 autólogos, 47 alogénicos y 5 haploidénticos. Se observaron tres reacciones de transfusión y 96 reacciones adversas. Las reacciones adversas están ligadas a presencia del crioprotector. Sin embargo, la velocidad de infusión y la cantidad del crioprotector infundido, no tuvieron relación con la ocurrencia de las reacciones. En las reacciones de transfusión, los productos eran frescos e infundidos con la velocidad preconizada. En cuanto a las fuentes de células, hubo menor tiempo de injerto en la sangre periférica. La documentación de enfermería es relevante tanto para la seguridad del paciente como para la planificación de la infusión, a fin de minimizar la ocurrencia de las reacciones.

Descriptores: Trasplante de Células Madre Hematopoyéticas / Reacciones Adversas; Transfusión de Componentes Sanguíneos; Enfermería.

\section{Introduction}

Bone marrow is the traditional source of hematopoietic stem cells but is currently being replaced by hematopoietic progenitor cells, especially for autologous transplantations, which is also found in peripheral blood; another source is umbilical cord blood.

Being aware of the condition and measures adopted during the entire process of reception and storage of bone marrow can contribute to a safe infusion, in preventing, identifying, minimizing or intervening in potential intercurrences or complications. In the context of a Bone Marrow Transplantation (BMT) unit, the presence of a nurse is essential because a nurse, when appropriately qualified, can provide technical and critical care and assist in the event of specific complications ${ }^{(1)}$. 
Given the complexity of care delivered to these patients, the Brazilian Federal Board of Nursing (COFEN) enacted Resolution 200/1997(2). It determines the competencies necessary for BMT nurses and one of these refers to specific technical procedures related to the aspiration and infusion of bone marrow, umbilical cord and peripheral blood hematopoietic precursors as well as planning and implementing actions aimed to reduce risks and optimize treatment results. Later, after reviewing and updating of this resolution, Resolution COFEN 306/2006(3) was published, which sets the rules for the work of nurses in hemotherapy.

Due to the risks inherent to the transfusion practice, one must know the incidents related to it and their frequency so that corrective and preventive measures are implemented to increase transfusion safety, which is the main objective of a blood-surveillance system ${ }^{(4)}$.

Patients might present reactions similar to those of a blood transfusion ${ }^{(5-6)}$ when cells are from the bone marrow. Transfusion reactions are negative health conditions that occur during or after blood transfusions. These can be classified as immediate or delayed, according to the time elapsed between the transfusion and the reaction ${ }^{(4)}$. The ANVISA (Brazilian National Health Surveillance Agency) understands an immediate transfusion reaction to be one that occurs during transfusion or up to 24 hours later; and a delayed reaction one that occurs 24 hours or more after the transfusion. The most frequent signs and symptoms are: malaise, tremors, chills, fever (above $38^{\circ} \mathrm{C}$ ), sweating, skin discoloration, myalgia, tachycardia, cyanosis, nausea and vomiting, among others ${ }^{(7)}$.

The Hematopoietic Stem Cells (HSC) used in autologous transplantations are usually cryopreserved because the patient undergoes cell collection, on average, 15 days prior to hospitalization for the transplant, a phase known as mobilization. Hence, due to the prolonged time of storage and the need to maintain cell viability, cryopreservation is necessary. The complications of an infusion with HSC of cryopreserved marrow or peripheral blood include cardiac alterations, dyspnea, nausea, vomiting, allergic reactions, hypotension, hypertension, tremors, fever, chest pain, feeling of constriction in the larynx, abdominal cramps, and exhalation of a characteristic odor for 24 to 36 hours. Some centers administer pre-infusion medication such as diphenhydramine or hydrocortisone in order to minimize discomfort ${ }^{(5,8)}$.

Adverse events after graft infusion are reported in about $80 \%$ of patients ${ }^{(9)}$, while nausea and vomiting are the most common ones ${ }^{(10)}$. A study comparing reactions among recipients of autologous cryopreserved bone marrow and fresh allogeneic marrow found statistical significance for a higher incidence of nausea, vomiting and fever for the former(11). In another study, $67.36 \%$ of patients presented allergic and gastrointestinal reactions and respiratory symptoms. These occurrences might be associated with age, the volume infused, level of DMSO, total nucleated cell count and total number of granulocytes $^{(12)}$.

Dimethyl sulfoxide (DMSO) cryoprotectant is known for its toxic reactions, but other factors can also cause reactions. Thus, during infusion, nurses must monitor vital signs, oxygen saturation, symptoms of fluid overload, acute hemolytic reaction, reaction to the DMSO, allergic or anaphylactic reaction. If a reaction is perceived, the nurse must reduce or cease infusion, immediately report to the physician, and administer medication and oxygen if necessary ${ }^{(13)}$.

Nurses should be informed about the source of cells, $A B O$ compatibility, storage regimen, treatment provided to the cells and strategies of transplantation in order to promote high quality care.

Based on these aspects, this study was developed with the following objectives: to identify the types of transplantations performed in the studied period; to characterize the transplantations performed in regard to the donors' and recipients' gender, kinship, blood type, ABO incompatibility, and $\mathrm{RH}$ factor incompatibility, the recipients' age, HSCT type, the cell source, interval between HSC collection and infusion, time for bone marrow engraftment, HSC treatment, quantity of infused DMSO, transfusion reactions, plasmapheresis in patient and infused volume; a goal, as well, is to identify the relationships among transfusions and acute adverse reactions and the HSCT type, HSC sources, quantity of infused DMSO and the volume infused.

\section{Method}

This retrospective and descriptive study collected data from transplantations performed from 2006 to 2008 through records in patients' medical files and databases of a university hospital and a transfusion unit in the interior of São Paulo, Brazil, after authorization of the involved institutions and approval from the Research Ethic Committee was obtained. Data refer to the days hematopoietic stem cell infusion was performed.

The following inclusion criteria were used: documental information for transplantations in subjects 
regardless of age; autologous transplantations for self-immune and hematological diseases; allogeneic transplantations with bone marrow or peripheral blood sources; transplantations with HSC, cryopreserved or not; transplantations performed between 2006 and 2008. Documental information of transplantations with simultaneous infusion of marrow and peripheral blood was excluded.

The data collection instrument, tested for face and content validity by five judges, contained the following items: donor's gender; recipient's gender; recipient's age; kinship; HSCT type; ABO/RH incompatibility; HSC source; HSC treatment; infused DMSO; transfusion reactions; plasmapheresis in patient; volume/weight relation; volume/weight/time relation; donor's blood type and recipient's blood type.
Information in the medical file of each patient was analyzed in relation to both clinical and nursing development, observing the presence of reactions during cell infusion over the first 24 hours. Adverse or transfusion reactions due to HSC were identified in the documentation of the hemotherapy service.

A database containing all studied variables was developed in MS Excel; variables were examined using descriptive statistics.

\section{Results}

According to the studied variables, the distribution of the types of transplantations evidenced 166 transplantations from relatives in the studied units between 2006 and 2008: $114(68.67 \%)$ autologous, 47 (28.31\%) allogeneic and five $(3.01 \%)$ haploidentical transplantations (Table 1 ).

Table 1 - Distribution of donors' characteristics (gender and blood type) and recipients' characteristics (gender, age, blood type) according to HSCT type. Ribeirão Preto, Brazil 2009

\begin{tabular}{|c|c|c|c|}
\hline \multirow{2}{*}{ Variable } & \multicolumn{3}{|c|}{ HSCT type } \\
\hline & Allogeneic & Autologous & Haploidentical \\
\hline \multicolumn{4}{|l|}{ Donor's gender } \\
\hline 1: Male & $29(61.70 \%)$ & - & 0 \\
\hline 2: Female & $18(38.30 \%)$ & - & $5(100.00 \%)$ \\
\hline 3: Not applicable & & $114(100.00 \%)$ & \\
\hline \multicolumn{4}{|l|}{ Recipient's gender } \\
\hline 1: Male & $23(48.94 \%)$ & $71(62.28 \%)$ & $3(60.00 \%)$ \\
\hline 2: Female & $24(51.06 \%)$ & $43(37.72 \%)$ & $2(40.00 \%)$ \\
\hline \multicolumn{4}{|l|}{ Recipient's age } \\
\hline 1: up to 11 years old & $1(2.13 \%)$ & 0 & $1(20.00 \%)$ \\
\hline 2: 12 to 18 years old & $4(8.51 \%)$ & $11(9.65 \%)$ & $2(40.00 \%)$ \\
\hline 3: 19 to 40 years old & $22(46.81 \%)$ & $53(46.49 \%)$ & $1(20.00 \%)$ \\
\hline $4: 41$ to 59 years old & $19(40.43 \%)$ & $38(33.33 \%)$ & $1(20.00 \%)$ \\
\hline $5: \leq$ than 60 years old & $1(2.13 \%)$ & $12(10.53 \%)$ & \\
\hline \multicolumn{4}{|l|}{ Kinship } \\
\hline 1: Siblings & $44(93.62 \%)$ & - & 0 \\
\hline 2: Parents & $3(6.38 \%)$ & - & $4(80.00 \%)$ \\
\hline 3: Others & & - & $1(20.00 \%)$ \\
\hline 4: Does not apply & & $114(100.00 \%)$ & \\
\hline \multicolumn{4}{|l|}{ Donors' blood type } \\
\hline 1: A & $19(40.43 \%)$ & - & $2(40.00 \%)$ \\
\hline 2: B & $3(6.38 \%)$ & - & 0 \\
\hline $3: A B$ & $1(2.13 \%)$ & - & 0 \\
\hline 4: 0 & $24(51.06 \%)$ & - & $3(60.00 \%)$ \\
\hline 5: Does not apply & & $114(100.00 \%)$ & 0 \\
\hline \multicolumn{4}{|l|}{ Recipient's blood type } \\
\hline $1: A$ & $16(34.04 \%)$ & - & $3(60.00 \%)$ \\
\hline 2: B & $6(12.77 \%)$ & - & $1(20.00 \%)$ \\
\hline $3: A B$ & & - & 0 \\
\hline 4: 0 & $25(53.19 \%)$ & - & $1(20.00 \%)$ \\
\hline 5: Does not apply & & $114(100.00 \%)$ & 0 \\
\hline
\end{tabular}

Most donors in allogeneic transplantations were male. Females predominated in the case of haploidentical transplantations; mothers are the preferred donors in this type of HSCT, in order to minimize the risk of 
rejection. There was a slight predominance of female recipients in the case of allogenic transplantations; while males predominated in haploidentical and autologous transplantations. Ages between 19 and 40 years old predominated for recipients both in the autologous and allogenic transplantations. However, the most frequent age range in the haploidentical transplantation was between 12 and 18 years old; the remaining ages were similar.

In relation to kinship observed in the allogeneic transplantation, the majority were siblings and the remaining were parents; mothers predominated in haploidentical transplantations. A high percentage of family members is observed in this service because it only performs HSCT among relatives. In regard to the donors' blood type, type A and type O prevailed among the allogenic and haploidentical transplantations. In relation to the recipients' blood type, type $A$ and type $O$ were more frequent in allogeneic transplantations. Type A was more frequent in haploidentical transplantations, equally followed by type $B$ and $O$.

In the relation between HSCT and the collection process, time of storage and infusion rate (Table 2 ), the following were considered: storage regime, choice of the donor and cells source, which were defined based on the underlying disease and the patient's clinical condition. It is observed that some of the autologous infusions did not present DMSO, while HSC were washed. There is a preference of infusing fresh products in the case of allogeneic and haploidentical HSCT. This is possible because marrow collection is scheduled for the same day of infusion, which is expected to diminish the chance of reactions.

In regard to cell source, there was a slight predominance of peripheral blood in the case of allogenic transplantations, and bone marrow in the case of haploidentical transplantations. Most of the infusions were performed with fresh products in allogenic transplantations, and similarly with the haploidentical transplantations. In the case of autologous transplantations, HSC were frozen due to the time required between collection and hospitalization for transplantation. Some products were washed during the autologous and allogenic transplantations, taking into account the patient's clinical condition, usually due to a compromised renal function. The erythrocyte depletion and deplasmatization processes that occurred in the allogenic and haploidentical transplantations (Table 2) were performed due to ABO system incompatibility. Almost no patient in this study underwent plasmapheresis.

Table 2 - Distribution of HSCT types according to DMSO quantity; HSC sources, time of collection and treatment; plasmapheresis; volume/time and volume/weight/time. Ribeirão Preto, Brazil 2009

\begin{tabular}{|c|c|c|c|}
\hline \multirow{2}{*}{ Variable } & \multicolumn{3}{|c|}{ HSCT Source } \\
\hline & Allogeneic & Autologous & Haploidentical \\
\hline \multicolumn{4}{|l|}{ DMSO } \\
\hline 1: up to $0.39 \mathrm{~g}$ & $6(12.77 \%)$ & 82 (71.93\%) & $1(20.00 \%)$ \\
\hline 2: 0.40 to $0.69 \mathrm{~g}$ & 0 & $17(14.91 \%)$ & 0 \\
\hline 3: 0.70 to $1.0 \mathrm{~g}$ & 0 & $6(5.26 \%)$ & 0 \\
\hline 4: Not mentioned & 0 & $6(5.26 \%)$ & 0 \\
\hline 5: Nothing & $41(87.23 \%)$ & $3(2.63 \%)$ & $4(80.00 \%)$ \\
\hline \multicolumn{4}{|l|}{ HSC sources } \\
\hline 1: Peripheral blood & $25(53.19 \%)$ & $114(100.00 \%)$ & $1(20.00 \%)$ \\
\hline 2: Bone Marrow & $22(46.81 \%)$ & 0 & $4(80.00 \%)$ \\
\hline \multicolumn{4}{|l|}{ HSC collection time } \\
\hline $1:<q .24 h$ & $38(80.85 \%)$ & 0 & $4(80.00 \%)$ \\
\hline 2: 25 to $48 \mathrm{~h}$ & $2(4.26 \%)$ & 0 & 0 \\
\hline $3:>49 h$ & $7(14.89 \%)$ & $114(100.00 \%)$ & $1(20.00 \%)$ \\
\hline \multicolumn{4}{|l|}{ HSC treatment } \\
\hline 1: Cryopreservation & $6(12.77 \%)$ & $111(97.37 \%)$ & $1(20.00 \%)$ \\
\hline 2: Erythrocyte depletion & $6(12.77 \%)$ & 0 & 0 \\
\hline 3: Washed & $2(4.26 \%)$ & $3(2.63 \%)$ & 0 \\
\hline 4: Deplasmatization & $1(2.13 \%)$ & 0 & $2(40.00 \%)$ \\
\hline 5: None & 32 (68.09\%) & 0 & $1(20.00 \%)$ \\
\hline 6: Mixed treatment & 0 & 0 & $1(20.00 \%)$ \\
\hline \multicolumn{4}{|l|}{ Plasmapheresis } \\
\hline 1:Yes & $4(8.51 \%)$ & $1(0.88 \%)$ & 0 \\
\hline 2:No & 43 (91.49\%) & 113 (99.12\%) & $5(100.00 \%)$ \\
\hline
\end{tabular}


Table 2 - Continuation

\begin{tabular}{|c|c|c|c|}
\hline \multirow{2}{*}{ Variable } & \multicolumn{3}{|c|}{ HSCT Source } \\
\hline & Allogeneic & Autologous & Haploidentical \\
\hline \multicolumn{4}{|l|}{ Volume/time } \\
\hline 1: up to $10 \mathrm{ml} / \mathrm{min}$. & $2(4.26 \%)$ & 67 (58.77\%) & 0 \\
\hline $2:>11 \mathrm{ml} / \mathrm{min}$ & $3(6.38 \%)$ & 37 (32.46\%) & $1(20.00 \%)$ \\
\hline 3: Does not apply & $42(89.36 \%)$ & $10(8.77 \%)$ & $4(80.00 \%)$ \\
\hline \multicolumn{4}{|l|}{ Volume/weight/time } \\
\hline 1: up to $6 \mathrm{ml} / \mathrm{Kg} / \mathrm{h}$ & $36(76.60 \%)$ & - & $3(60.00 \%)$ \\
\hline $2:>7 \mathrm{ml} / \mathrm{Kg} / \mathrm{h}$ & $1(2.13 \%)$ & - & 0 \\
\hline 3: Does not apply & $10(21.28 \%)$ & $114(100.00 \%)$ & $2(40.00 \%)$ \\
\hline
\end{tabular}

It was observed that most of the HSC infusions occurred within the recommended time. It is important to note that the infusion rate must be controlled according to the characteristics of the product to be infused and also according to the patient's clinical condition.

In regard to the distribution of incompatibilities and occurrence of reactions (Table 3 ), although there was a relative percentage of $A B O$ and $\mathrm{RH}$ incompatibility, the number of transfusion reactions was small. It is important to keep in mind that these reactions were reported to the hospital transfusion agency by the hematologist physician present at the time. Adverse reactions that occurred in the infusion of cryopreserved products were reported by the physician responsible for the transfusion agency in a specific form from the service or by the physician of the bone marrow transplantation unit. There was $12.77 \%$ of major incompatibility in the allogenic transplantations. RH incompatibility, both major $(4.26 \%)$ and minor (4.26\%), occurred in the allogenic HSCT. In this situation, the marrow bag needs to be deplasmatized to withdraw the antibody supernatants from plasma.

Table 3 - Distribution of the HSCT type according to ABO and RH incompatibility, transfusion and adverse reactions in cell infusion. Ribeirão Preto, Brazil 2009

\begin{tabular}{|c|c|c|c|}
\hline \multirow{2}{*}{ Variable } & \multicolumn{3}{|c|}{ HSCT type } \\
\hline & Allogenic & Autologous & Haploidentical \\
\hline \multicolumn{4}{|l|}{ Incompatibility $\mathrm{ABO}$} \\
\hline 1: Yes. major & $6(12.77 \%)$ & - & \\
\hline 2: Yes. minor & $4(8.51 \%)$ & - & $2(40.00 \%)$ \\
\hline 3: No & $34(72.34 \%)$ & - & $2(40.00 \%)$ \\
\hline 4: bidirectional & $3(6.38 \%)$ & - & $1(20.00 \%)$ \\
\hline \multicolumn{4}{|l|}{ Incompatibility RH } \\
\hline 1: Yes. major & $2(4.26 \%)$ & - & \\
\hline 2: Yes. minor & $2(4.26 \%)$ & - & \\
\hline 3: No & $43(91.49 \%)$ & - & $5(100.00 \%)$ \\
\hline \multicolumn{4}{|l|}{ Transfusion Reactions } \\
\hline 1:Yes & $3(6.38 \%)$ & & \\
\hline 2: No & $41(87.23 \%)$ & $114(100.00 \%)$ & $5(100.00 \%)$ \\
\hline 3: Not mentioned & $3(6.38 \%)$ & 0 & \\
\hline \multicolumn{4}{|l|}{ Adverse Reactions } \\
\hline 1:Yes & $10(21.27 \%)$ & $84(73.68 \%)$ & $2(40.00 \%)$ \\
\hline 2: No & $37(78.72 \%)$ & $30(26.32 \%)$ & $3(60.00 \%)$ \\
\hline
\end{tabular}

We opt for considering adverse reactions as those reactions presented during the cryopreserved HSC infusion due to the association with the cryoprotectant. Although such reactions also occurred during allogenic HSCT $(21.27 \%)$, they were more frequent $(73.68 \%)$ in autologous HSCT. It was observed that transfusion reactions occurred with fresh products, while $66.67 \%$ were from bone marrow source, with infusion up to 6 $\mathrm{ml} / \mathrm{Kg} /$ hour (Table 4). 
Table 4 - Distribution of transfusion and adverse reactions according to DMSO quantity, HSC sources, relation volume/weight/time and volume/time of infusion. Ribeirão Preto, Brazil 2009

\begin{tabular}{lcc}
\multicolumn{1}{c}{ Variable } & $\begin{array}{c}\text { Transfusion } \\
\text { Reaction }\end{array}$ & Adverse Reaction \\
\hline DMSO & - & $66(68.75 \%)$ \\
1: up to $0.39 \mathrm{~g}$ & - & $15(15.62 \%)$ \\
2: 0.40 to $0.69 \mathrm{~g}$ & - & $5(5.20 \%)$ \\
3: 0.70 to $1.0 \mathrm{~g}$ & - & $5(5.20 \%)$ \\
4: Not mentioned & $3(100.00 \%)$ & $5(5.20 \%)$ \\
5: Nothing & $1(33.33 \%)$ & $47(67.61 \%)$ \\
HSC sources & $2(66.67 \%)$ & $23(32.39 \%)$ \\
1: Peripheral blood & & \\
2: Bone Marrow & $3(100.00 \%)$ & - \\
Volume/weight/time & 0 & - \\
1: up to $6 \mathrm{ml} / \mathrm{Kg} / \mathrm{h}$ & & $53(34.37 \%)$ \\
2: $>$ 7 ml/Kg/h & - & $13(13.54 \%)$ \\
Volume/time & - & \\
1: up to $10 \mathrm{ml} / \mathrm{min}$. & - & \\
2: $>11 \mathrm{ml} / \mathrm{min}$. & & \\
3: Does not apply & & \\
\hline
\end{tabular}

Among the adverse reactions, $68.75 \%$ occurred in infusions with smaller quantities of DMSO. A total of $96.84 \%$ of patients whose cell source was peripheral blood had adverse reactions; reactions were also observed in patients whose cell source was bone marrow.

In regard to the infusion rate, even patients (52.08\%) with autologous transplantation who were infused at a rate of up to $10 \mathrm{ml} / \mathrm{min}$ presented adverse reactions; $34.37 \%$ of patients had a faster rate of infusion and also developed such reactions.

\section{Discussion}

The distribution of transplantation types observed in this study is corroborated by data from the Brazilian Registry of Transplantation, which indicates that the number of autologous transplantations was greater than the number of the allogenic type in the first quarter of 2009. Transplantation from relatives is still prevalent when compared to non-relative transplantation, which has increased in recent years ${ }^{(14)}$. The recipients' characteristics concerning age range and gender are related to their pathology.

Findings regarding the donors' gender are similar to national(14) ones and to those of one study carried out in Turkey with a marked prevalence of male recipients in autologous transplantations ${ }^{(15)}$.

The obtained incidence of blood type derives from data from the Brazilian Association of Organ Transplantation (ABTO) in which type O occurs in $49 \%$ of cases and type A occurs in 33\% of organ and tissue donors (Table 1).

In the case of $A B O$ incompatibility between donor and recipient, transplantation is subject to some complications: acute hemolysis, delayed erythropoiesis, late hemolysis, among others ${ }^{(8)}$; and depletion of red blood cells should be considered in order to minimize the occurrence of hemolytic reactions ${ }^{(16)}$. The inheritance of blood group antigens does not depend on inheritance of major histocompatibility antigen (HLA). Incompatibility of the $A B O$ system does not define transplantation success because the clinical importance lies in HLA compatibility. The HSC donor and recipient can have different blood groups and still present HLA compatibility ${ }^{(8)}$.

Major incompatibility was identified in this study in a discreet number of allogenic transplantations and minor incompatibility in some haploidentical transplantations (Table 3). Major ABO incompatibility is relevant information for nurses who will perform cell infusions. In this type of transplantation, the bag erythrocyte depletion occurs and nurses must verify the final number of red blood cells at the time $s /$ he receives the product. This volume can trigger the occurrence of a transfusion reaction if not within the permitted limits, that is, less than $0.5 \mathrm{ml} / \mathrm{kg}$ of the recipient's weight ${ }^{(17)}$. In the event of minor $A B O$ incompatibility, the marrow bag has to be deplasmatized so that antibody supernatants are withdrawn from the plasma.

Incompatibility involving the Rh system can lead to late alloimmune hemolysis (major incompatibility) and hemolysis in $10 \%$ to $15 \%$ of patients (minor type). Rh incompatibility was not observed in almost all transplantations.

The occurrence of reactions during HSC infusion can also be related to its source, total volume, cell treatment, use of cryoprotectant (DMSO), ABO compatibility and infusion rate. In this study (Table 2) the major source of stem cells for the autologous and allogenic transplantations was peripheral blood, with time of collection less than 24 hours before the infusion for the allogenic and haploidentical transplantations and more than 49 hours before infusion for the autologous transplantations; cells were not treated in most of the allogeneic transplantations; cryopreservation was performed in almost all the autologous transplantations; deplasmatization and cryopreservation were observed in some haploidentical transplantations; there was no plasmapheresis in the majority of patients in the allogeneic transplantations; infusion rates were up to $10 \mathrm{ml} / \mathrm{min}$ predominated in the autologous transplantation and 
up to $6 \mathrm{ml} / \mathrm{kg} /$ hour in the allogenic and haploidentical transplantation.

One hypothesis for the development of adverse reactions related to the infusion of thawed graft is the amount of DMSO administered; in products in which DMSO was depleted, this relation of HSC volume infused is attributed to the residual amount of DMSO and to the number of granulocytes presented(14).

In this study, data of transfusion or adverse reactions in relation to the presence of DMSO, the volume infused and cell source, indicated that the three transfusion reactions occurred with the use of products without DMSO, when peripheral blood or marrow cells were the source, when the infusion rate was up to $6 \mathrm{ml} / \mathrm{kg} /$ hour. The adverse reactions occurred predominantly with the use of products with up to $0.39 \mathrm{~g}$ of DMSO, peripheral blood and in infusions of up to $10 \mathrm{ml} /$ hour $(52.08 \%)$ (Table 4). The concentration of DMSO generally used, between $5 \%$ and $10 \%$, ensures the viability of cells and graft capacity. The maximum recommended dose of DMSO to be infused is $1 \mathrm{~g} / \mathrm{kg}$ or $10 \mathrm{ml} / \mathrm{kg}$ of DMSO solutions at $10 \%{ }^{(18)}$.

Given the severity and high incidence of adverse reactions, one possible preventive measure is washing the cells with cell washers in order to remove DMSO, free hemoglobin and cellular debris. In this study, washed cells were used in five transplantations due to the patients' clinical conditions and the cryoprotectant's potential toxicity. The plasmapheresis procedure aims to reduce the anti-A or anti-B hemagglutinins presence in the recipient's plasma. The antibody titer in the patient's blood is usually high in the case of multiple transfusions. The major disadvantage of this method is the risk of transfusion reactions due to the use of fresh frozen plasma in replacing the volume of removed plasma(19).

During cell infusion, products containing HSC cannot be irradiated or transfused with equipment with leukoreduction because these procedures can harm or eliminate cells. In addition, it is necessary to minimize the contact of cells with DMSO, which would lead to a faster infusion. To determine infusion rate, the volume of cells in relation to the patient's volume of blood, quantity of DMSO in the product and the product's temperature should be taken into account. The recommended infusion for products with DMSO at $10 \%$ is between 5 to $20 \mathrm{ml} / \mathrm{min}^{(6)}$. For patients that receive non-frozen bone marrow, the following parameters are recommended since transfusion reactions common to other blood products can develop(12). In this study, a slight majority of patients who presented adverse reactions were infused at up to $10 \mathrm{ml} / \mathrm{min}$. The infusion of blood products is performed at a rate of 3 to $6 \mathrm{ml} /$ $\mathrm{kg} /$ hour, though it can be slower in the case of more vulnerable individuals, at $1 \mathrm{ml} / \mathrm{kg} /$ hour $^{(17)}$. All the patients who presented transfusion reactions were infused at up to $6 \mathrm{ml} / \mathrm{kg} / \mathrm{h}$ (Table 4 ).

The conclusion regarding the occurrence of transfusion reactions is that these occurred in infusions with fresh products (without DMSO), of peripheral blood and bone marrow sources, while infusion rate followed the recommendations in the literature. Most adverse reactions occurred in autologous transplantations, all from peripheral blood sources. A larger number of reactions occurred with smaller quantities of DMSO and in infusions in which the infusion rate was performed as recommended.

Being aware, trained and attentive to prevent, identify, address and treat potential transfusion reactions is the duty of all health professionals dealing with transfusions $^{(4,8)}$. In addition to the service organization ${ }^{(20)}$, the importance of the organization of care is highlighted, especially in relation to the documentation of information and organization of clinical data. These aspects favor the efficient recording of rational and objective decisionmaking, revealing care appropriate to the needs of patients $^{(21)}$, as well as promoting the prevention or early identification of other adverse events related to the devices used in transfusions such as the central venous catheter whose rate of adverse events, though rare in the hospital setting(22), can compromise the cell infusion procedure. From this perspective, this study supports nurses' clinical rationale in improving the safety of patients in the context of transfusion care because it identifies variables of interest in HSCT situations and related adverse and transfusion reactions.

\section{Final Considerations}

As evidenced in this study, reactions can occur with fresh or cryoprotectant products, originating from peripheral or bone marrow sources, even when infused within the recommended rate. The adoption of strategies that lead nurses to know the conditions of the process of collection, treatment and storage of products to be infused promotes the observation of adverse and/or transfusion reactions and facilitates their identification. In addition, recording the entire infusion process enables understanding nursing care delivery and favors control of adverse events that occur during HSC infusion. 


\section{References}

1. Lacerda MR, Lima JBG de, Barbosa R. Prática de enfermagem em transplante de células tronco hematopoiéticas. Rev Eletr Enferm. 2007; 9(1):242-50.

2. Conselho Federal de Enfermagem, Resolução COFEN 200/1997. Regulamento da atuação dos Profissionais de Enfermagem Hemoterapia e transplante de medula óssea. Rio de Janeiro: COFEn; 1997.

3. Conselho Federal de Enfermagem, Resolução COFEN 306/2006. Normatiza a atuação do enfermeiro em hemoterapia. Rio de Janeiro: COFEn; 2006.

4. Agência Nacional de Vigilância Sanitária. Hemovigilância: manual técnico para investigação das reações transfusionais imediatas e tardias não-infecciosas [homepage na internet] 2007 [acesso em: 24 fev 2008]. Disponível em: http://www. anvisa.gov.br.

5. Bonassa EMA, Santana, TR. Enfermagem em terapêutica oncológica. 3a ed. São Paulo (SP): Atheneu; 2005.

6. Sauer-heilborn A, Kadidlo D, Mccullough J. Pacient care curing infusion of hematopoietic progenitor cells. Transfusion. 2004; 44 (6):907-16.

7. Ludwig L, Zilly A. Reações transfusionais ligadas ao sistema ABO. NewsLab. 2007; 84 (1):102-12.

8. Ortega ETT, Kojo TK, Lima DH de, Veran MP, Neves MI. Compêndio de enfermagem em transplante de células tronco hematopoiéticas - Rotinas e procedimentos em cuidados essenciais e em complicações. Curitiba (PR): Maio; 2004.

9. Larghero J, Rea D, Esperou H, Biscay N, Maurer MN , Lacassagne MN. ABO-mismatched marrow processing for transplantation: results of 114 procedures and analysis of immediate adverse events and hematopoietic recovery. Transfusion., 2006; 46 (3):398-402.

10. Kim DH, Jamal N, Saragosa R, David Loach D, Wright J, Gupta V, Kuruvilla J, Lipton JH, Minden M, Messner HA. Similar outcomes of cryopreserved allogeneic peripheral stem cell transplants (PBSCT) compared to fresh allografts. Biol Blood Marrow Transplant., 2007; 13(10):1233-43.

11. Stroncek DF, Fautsch SK, Lasky LC, Hurd DD, Ramsay NK, McCullough J. Adverse reactions in patients transfused with cryopreserved marrow. Transfusion., 1991; 31(6):521-6.
12. Cordoba R, Arrieta R, Kerguelen A, Hernandez-Navarro F. The occurrence of adverse events during the infusion of autologous peripheral blood stem cells is related to the number of granulocytes in the leukapheresis product. Bone Marrow Transplant. 2007; 40(11):1063-7.

13. Rodriguez AL, Tariman JD, Enecio T, Estrella SM. The role of high-dose chemotherapy supported by hematopoietic stem cell transplantation in patients with multiple myeloma: implications for nursing. Clin J Oncol Nurs. 2007; 11(4):579-89.

14. Associação Brasileira de Transplantes de Órgãos. J Bras Transplantes [homepagen na internet] 2009 [acesso em 25 março 2009]. Disponível em: http://www.abto.org.br

15. Donmez A, Tombuloglu M, Gungor A, Soyer N, Saydam G, Cagirgan $S$. Clinical side effects during peripheral blood progenitor cell infusion. Transfus Apheresis Sci. 2007; 36(1):95-101.

16. Castro JrCG, Gregianin LJ, Brunetto AL. Transplante de medula óssea e transplante de sangue de cordão umbilical em pediatria. J Pediatr. 2001; 77 (5):345-60.

17. Universidade de São Paulo. Faculdade de Medicina de Ribeirão Preto. Hospital das Clínicas. Centro Regional de Hemoterapia. Manual de medicina transfusional (MMT). Ribeirão Preto: USP/ FMRP/HC; 2007.

18. Mendrone A Jr, Arrais CA, Saboya R, Velasques RD, Junqueira $\mathrm{PL}$, Dulley FL. Neurotoxicity associated with dimethylsulfoxidepreserved hematopoietic progenitor cell infusion. Bone Marrow Transplant. 2008; 41(1):95-6.

19. Mendrone $A$ Jr. Incompatibilidade $A B O$ no transplante de medula óssea [Internet] 1997 [acesso em 17 março 2007]. Disponível em: URL:http://www.hemonline.com.br

20. Riul S, Aguiar OM. Contribution to the organization of the service of bone marrow transplantation and nurse's performance. Rev. Latino-Am. Enfermagem. 1997; 5(1):49-58.

21. Santos SR, Paula AFA, Lins JP. Nurses and their perception about the manual recording system in patients' files. Rev. LatinoAm. Enfermagem. 2003; 11(1):80-7.

22. Nascimento CCP, Toffoletto MC, Gonçalves LA, Freitas WG, Padilha KG. Indicators of healthcare results: analysis of adverse events during hospital stays. Rev. Latino-Am. Enfermagem. 2008; 16(4):746-51.

Received: Jul. $19^{\text {th }} 2009$

Accepted: Mar. $3^{\text {rd }} 2010$ 